\title{
Feeding, Fat Deposits and Growth of Sand-Eels in Ise Bay, Central Japan
}

\author{
Hideo Sekiguchi, ${ }^{*}$ Makoto Nagoshi, ${ }^{*}$ Kazushi Horiuchi, ${ }^{*}$ \\ and Noboru NAKANISH ${ }^{*}$
}

(Received March 10, 1976)

\begin{abstract}
Feeding, fat deposits and growth of sand-eels (Ammodytes personatus) were examined by taking samples from the Tsu fish market from 25th February to 29th May 1974.

The rapid growth and accumulation of fat, in accordance with voracious feeding, was observed shortly before the sand-eels entered the dormant state they pass through in summer. Sand-eels in this state depend for their life on the nutritional accumulation gained beforehand. So it is deduced that the nutritional condition in May, shortly before the sand-eels pass into a dormant state, would have a great influence on their survival and also on the potential of the resources of Ise Bay.
\end{abstract}

In Ise Bay, one of the most eutrophic inlet waters in Japan, planktivorous fishes make the largest contribution to fish production. ${ }^{13}$ Planktivorous fishes in Ise Bay include sand-eel, Ammodytes personatus, and anchovy, Engraulis japonica, which amount to a total of $13000-40000$ ton/year during the last ten years. It is well known that sandeels show particular ecological behaviour- aestivation. In Ise Bay, adults of sand-eel spawn in the outside of the Irago passage. Then, the larvae and juveniles migrate into the bay and are fished until early in June, when they burrow into the sandy mud to pass the summer in a dormant state. ${ }^{2,3}$ Out of the larval stages, the fish largely depend on copepods such as Calanus and Acartia in the bay. ${ }^{4}$

In the present paper, the authors deal with the feeding, fat deposit and growth of sand-eels especially in relation to their ecological characteristics.

\section{Materials and Methods}

The samples were obtained from Tsu fish market from 25th February to 29th May 1974 although a few of the larvae were collected at Shiroko fish market and Toshi Island (Fig. 1). Since the samples were taken from the market where almost all of the sand-eels fished in the bay are landed, they must represent the stock of sand-eels in the bay.

Bady length (standard length) and weight were measured on 300 individuals in each sampling time. For measurement of dry matter, 50 fish were weighed, after being dried at $100^{\circ} \mathrm{C}$ for $24 \mathrm{hr}$ and then desiccated over silica gel for $48 \mathrm{hr}$. The wet weight of

* Faculty of Fisheries, Mie University, Edobashi, Tsu, Mie, Japan（關口秀夫・名越 誠・堀内和司・ 中西 舁: 三重大学水産学部) 


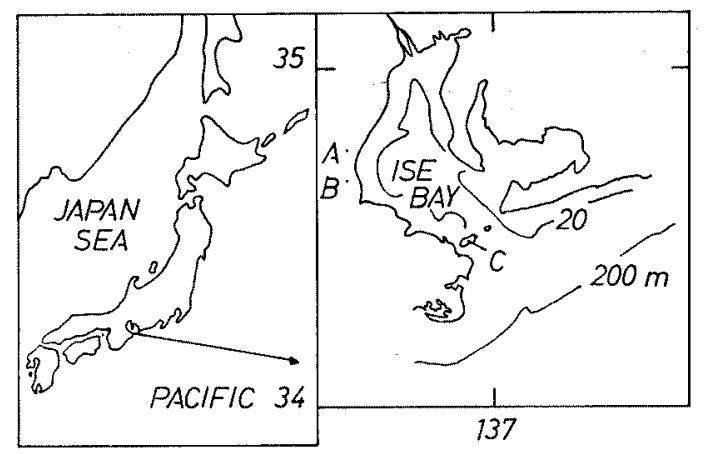

Fig. 1. Map of area studied.

A: Shiroko, B: Tsu, C: Toshi Island

stomach contents of these fish was recorded, individually for the fish larger than $45 \mathrm{~mm}$ in body length, and on the combined specimen of ten fish for the smaller fish. The fat was estimated as the difference of dry weight before and after being extracted with ether for $6 \mathrm{hr}$ according to the Soxhlet method.

\section{Results and Discussion}

In Fig. 2 the maximal weight of stomach contents and feeding rate (maximal weight of stomach contents/body weight) are plotted against the date of collection with reference to their body length. The mean weight of stomach contents may not necessarily represent the feeding activity because it varies due to various factors such as catching time and so on. The maximal weight of stomach contents, however, must show rough tendency of fluctuation of feeding activity against the date of collection. Though the values fluctuate very widely during the period surveyed, they display a similar pattern with peaks in March, April and May, the peaks being $8 \mathrm{mg}$ (3.3\%), $35 \mathrm{mg}(6.2 \%)$ and $81 \mathrm{mg} \mathrm{(4.4 \% )}$ in order for the weight of stomach contents (or feeding rate). The date when the peaks appear coincide well from early March to early May regardless of the body length, but after this time each group at a given length display its maxima at a different date, although the discrepancy between the dates for the maxima being not much (Fig. 2). Fishing operations of sand-eels are done after sunrise when the fish emerge from the sand. ${ }^{5)}$ Sand-eels feed during the daytime in relation to their diurnal behaviour. ${ }^{6)}$ It is not known why the feeding activity of sand-eels caught in the daytime fluctuates very widely with the date of collection. A possible cause is that the fluctuation of feeding activity may compare to that of standing crops of zooplanktons as reported in ccrnish pilchard, ${ }^{7 /}$ although it is impossible to compare the fluctuation of feeding activity with that of standing crops of zooplanktons in our study. 

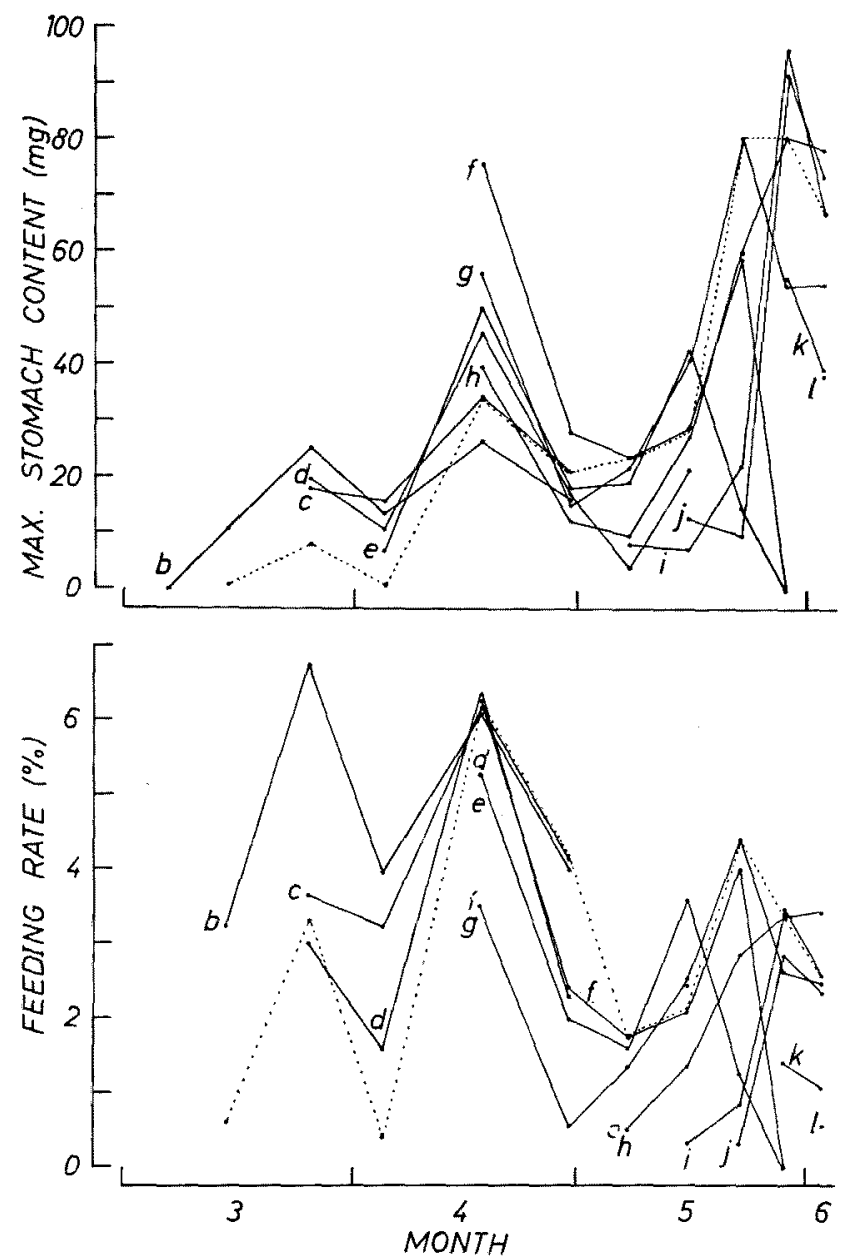

Fig. 2. The weight of stomach contents (upper) and feeding rate (lower) of sand-eels.

"a-j" indicate the length as follows; a: less than $45 \mathrm{~mm}, \mathrm{~b}: 45-50 \mathrm{~mm}, \mathrm{C}: 50-55 \mathrm{~mm}$, d: $55-60 \mathrm{~mm}$, e: $60-65 \mathrm{~mm}, \mathrm{f}: \quad 65-70 \mathrm{~mm}, \mathrm{~g}: 70-75 \mathrm{~mm}, \mathrm{~h}: 75-80 \mathrm{~mm}, \mathrm{i}: 80-85 \mathrm{~mm}$, j: $85-90 \mathrm{~mm}$ body length.

The dot line indicates that of mean body length.

The percentage of fat content increases with increasing body weight (Fig. 3). The percentage, however, remains relatively low in sand-eels less than $45 \mathrm{~mm}$ length (Fig. 4), which are found in the samples obtained early May when the weight of stomach contents and feeding rate are at a minimum. The percentage of fat in the fish of a given length shows a similar fluctuation against the date of collection during the period examined, and increases rapidly in May (Fig. 5). The dry weight of a given length shows a similar fluctuation against the date of collection and rapidly increases in May, although the details of the fluctuation differs from that of the fat deposit (Fig. 6). 


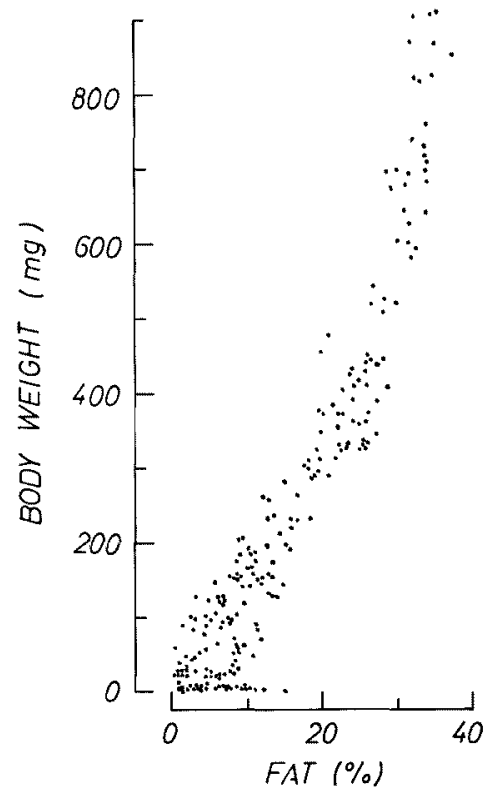

Fig. 3. Fat $(\%$, fat content/dry body weight) - dry body weight (mg) relationship.

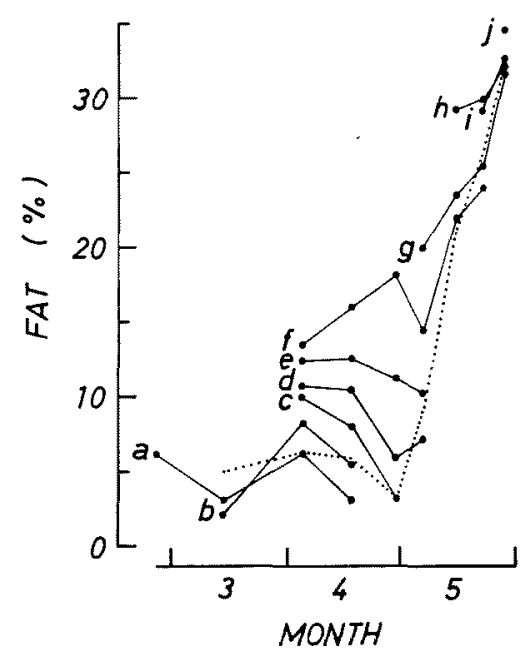

Fig. 5. Fat percentage (fat content/dry body weight) of sand-eels The dotted line indicates that of mean body length.

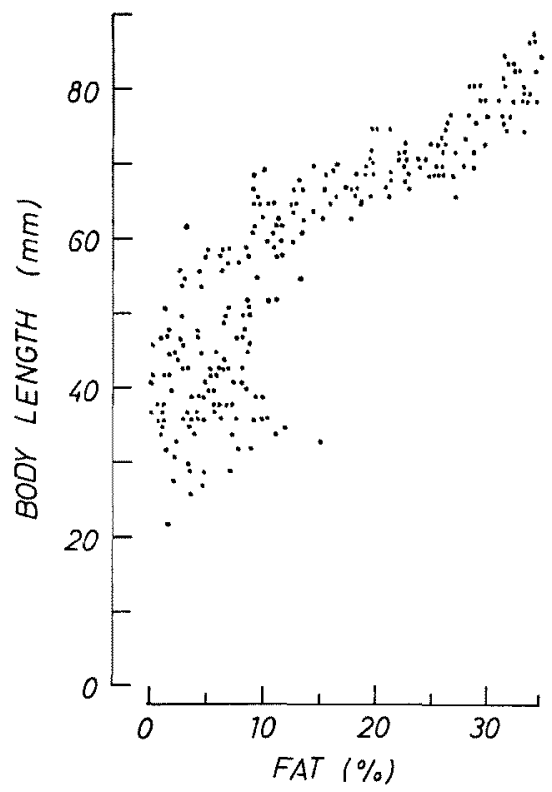

Fig. 4. Fat $(\%$, fat content/dry body weight)-body length $(\mathrm{mm})$ relationship.

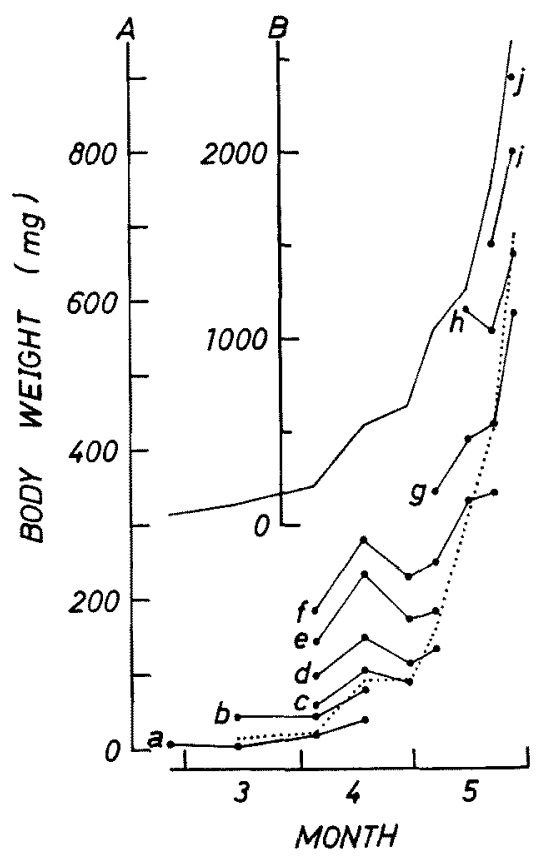

Fig. 6. Mean body weight of sand-eels.

A: dry weight, B: wet weight The dotted line indicates that of mean body length. 
Sand-eels in Ise Bay, which are composed of $0^{+}$year class, are caught from March to early June before they dive into the sandy mud to pass the summer in a dormant state. ${ }^{2,3)}$ It is deduced that the rapid fat deposit, which occurs shortly before the fish enter the dormant state, supplies energy for aestivation. Besides the sand-eels in Ise Bay, the rapid increment of growth and fat deposit have also been observed before dormancy of winter in the North Atlantic ${ }^{8\rangle}$ and of summer in Japan., ${ }^{91}$ After the fishing season has ended in early June in Ise Bay, the adults or spawners are caught in the deep water of the Irago passage from early November or December. It has been known by fishermen that the sand-eels, which are caught at first on the spawning ground, are very lean, as reported by REAY ${ }^{9)}$ and INOuE et $a .^{101}$ in other fishing area. It may be concluded that sand-eels in a dormant state of the summer depend for their life on the fat accumulated shortly beforehand. The nutritional condition would have a great influence on the survival of sand-eels of the summer, buried in the sandy mud, and further on the potential of the resources of Ise Bay.

\section{Acknowledgement}

The authors heartly thanks the staffs of Ise-wan Fisheries Research Laboratory, Mie Prefecture, for their assistance of collecting samples. Sincere thanks are due to Dr. R. M. Love, Torry Research Station, and Dr. P. J. Reay, School of Environmental Sciences, Plymouth Polytechnics, for their valuable criticisms and suggestions.

\section{References}

1) T. Hanaoka: Inf. Coast. Oceanogr., 7, 24-27 (1969).

2) Y. Oshma: This Bull., 16, 99-107 (1950).

3) M. Mryamura and T. Sugno: Bull. Ise-wan Reg. Fish. Res. Lab, 1, 1-9 (1959).

4) H. Sekiguchi, M. Nagosht, Y. Mori and Y. Kato: Bull. Fac. Fish., Mie Univ., 1, 33-44 (1974).

5) C. T. MACER: Fish. Inves., ser. 2, 24, 1-55 (1966).

6) S. Motoda and Y. TANAKA: Bull. Hokkaido Reg. Fish. Res. Lab., 7, 56-61 (1950).

7) C. F. Hicklng: J. Mar. Biol. Ass. U. K., 26, 115-138 (1945).

8) T. Ishigakl and K. Kato: Bull. Hokkaido Reg. Fish. Res. Lab., 16, 13-37 (1957).

9) P. J. ReAY: J. Mar. Biol. Ass. U.K., 53, 325-346 (1973).

10) A. Inoue, S. Takahashi, K. Kunish, S. Kobayashi and S. Nishina: Bull. Naikai Reg. Fish. Res. Lab., 25, 1-336 (1967). 